DOI: https://doi.org/10.32626/2227-6246.2019-46 2019. Випуск 46

UDC 159.942:[616.891.6+616.89-008.441]:612.017.2

уДК 159.942:[616.891.6+616.89-008.441]:612.017.2

\title{
The Issue of the Researching Psychological Characteristics of Rational and Pathological Anxiety in the Clinic of Endogenous Mental Illnesses
}

\section{Проблематика досліджень психологічних особливостей раціональної та патологічної тривоги в клініці ендогенних психічних}

захворювань

Natalia Zaviazkina

Ph.D. in Psychology, Assistant Professor, Taras Shevchenko National University of Kyiv, Kyiv (Ukraine)

ORCID ID: https://orcid.org/0000-0001-5565-8959

E-mail:nmuz@ukr.net

\section{Наталія Завязкіна}

Кандидат психологічних наук, доцент, Кииївький національний університет імені Тараса Шевченка, м. Київ (Україна)

\section{Tetiana Riakhovska}

Postgraduate Student, Department of Clinical Psychology, Kyiv Institute of Modern Psychology and Psychotherapy, Kyiv (Ukraine)

ORCID ID: https://orcid.org/0000-0002-7280-5129

E-mail: TLRyakhovska@gmail.com

\section{Тетяна Ряховська}

Аспірант кафедри клінічної психології, Київський інститут сучасної психології та психотерапії, м. Київ (Україна)

Address for correspondence, e-mail: kpnu_lab_ps@ukr.net Copyright: (C) Zaviazkina Natalia, Riakhovska Tetiana

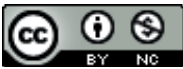

The article is licensed under CC BY-NC 4.0 International (https://creativecommons.org/licenses/by-nc/4.0/)

(C) Zaviazkina Natalia, Riakhovska Tetiana DOI (article): https://doi.org/10.32626/2227-6246.2019-46.135-156 
DOI: https://doi.org/10.32626/2227-6246.2019-46

The author's contribution: N. Zaviazkina $-50 \%$, T. Riakhovska $-50 \%$.

Авторський внесок: Н. Завязкіна - 50\%, Т. Ряховська - 50\%.

\section{ABSTRACT}

The article examines the theoretical aspects of the history of development of concepts of anxiety and anxiety states. Special attention is drawn in particular to analysis of understanding the rational and pathological anxiety and peculiarities of its manifestations in neurotic and psychotic states. Among the methods used in the research there are comparison and correlation of existing historical and modern theories and approaches to the study of anxiety and anxiety states, their definitions in psychology and psychiatrics that became the theoretical and methodological foundation of the present research.

It is found that the majority of authors make a distinction between the pathological anxiety and rational anxiety by the level of affect intensity, its duration, adequacy of potential danger, inclusion of mechanisms of psychological defense, influence on quality of life of a patient.

The rational anxiety is of adaptive character, it makes the whole body adapt to new living conditions. Thus, the adaptive character of the rational anxiety makes it an interim option between true anxiety and fear. In case of some pathology, the transition of true anxiety into fear happens to be quicker (delusion in case of schizophrenia, agoraphobia or other kinds of phobias in case of anxiety disorders). Thus, the rational anxiety already contains the elements of the pathological anxiety.

It is concluded that, up to this day, many works have examined the problem of comparative analysis of the phenomenon of anxiety in neurotic and psychotic states. However, the main attention of the majority of scholars, who research the present issue, was focused on confirmation of the differences, but not on search for the mechanisms that unite them. The adaptive strategies means for anxiety elimination may prove to be such mechanisms.

Key words: anxiety, fear, neurotic state, rational anxiety, pathological anxiety, endogenous mental illness, adaptation.

\section{Вступ}

Уважного ставлення вчених останнім часом вимагає питання дослідження тривоги, що є одним із найбільш руйнівних психологічних станів, відомих на сьогодні.

(C) Zaviazkina Natalia, Riakhovska Tetiana

DOI (article): https://doi.org/10.32626/2227-6246.2019-46.135-156 http://journals.uran.ua/index.php/2227-6246 
Тривожний домінуючий афект є основним діагностичним критерієм розладів невротичного рівня. Необхідно підкреслити, що є численні варіанти психопатологічних станів, коли тривожний афект домінує лише на початковому етапі, існуючи надалі з великою кількістю іншої психопатологічної симптоматики, яку не можна віднести до тривожної. Тривога в цих випадках виступає як афективне тло, що дає початок симптоматиці інших психопатологічних регістрів.

Якщо брати до уваги той факт, що тривога є універсальним феноменом, як для здорової людини, так і для людини, яка страждає на психічний розлад будь-якого рівня, виявляється логічним припустити, що механізми адаптації до тривоги також будуть схожими. Саме це обумовлює важливість дослідження тривожних станів у хворих із розладами психотичного рівня.

Тривожні стани при шизофренії все частіше описуються й досліджуються, на них спрямовано лікування, оскільки в останні роки зростає усвідомлення наявності та потенційної значущості супутніх до неї захворювань. Це узгоджується з епідеміологічними дослідженнями, що показують високу поширеність супутніх психічних захворювань у пацієнтів із шизофренією (Bermanzohn et al., 2001).

Тривожні стани можуть передувати збільшенню загальної тяжкості симптомів основного захворювання і погіршенню прогнозу (Karpov et al., 2016). 3 іншого боку, адекватне діагностування та лікування цих станів може призводити до значних полегшень, як позитивних так і негативних психотичних симптомів (Bermanzohn et al., 2001).

Симптоми тривоги можуть виникати у $65 \%$ пацієнтів із шизофренією і можуть досягати порогових значень у діагностуванні різних супутніх тривожних розладів (Temmingh \& Stein, 2015). Майже у 50\% випадків ці симптоми досягають тяжкого ступеня (Karpov et al., 2016).

Тривога або у формі симптому, або у формі одного або декількох синдромів тривоги, зазвичай, виникає у пацієнтів,

(C) Zaviazkina Natalia, Riakhovska Tetiana DOI (article): https://doi.org/10.32626/2227-6246.2019-46.135-156 
у яких діагностовано шизофренію. Синдроми тривоги, що потенційно виникають при шизофренії, включають обсесивно-компульсивний розлад, панічний розлад, посттравматичний стресовий розлад, соціальну фобію, специфічні фобії та генералізований тривожний розлад. Будь-який із них або всі ці тривожні розлади можуть бути джерелом значних страждань і дисфункції та є важливими цілями для терапевтичного втручання (Braga, Reynolds \& Siris, 2013).

Вираженість позитивних симптомів може корелювати 3 вираженістю симптомів тривоги, але тривога може виникати незалежно від психотичних симптомів (Temmingh \& Stein, 2015).

Наявність продуктивної симптоматики при шизофренії ускладнює діагностику тривоги. Вищий діагностичний результат може бути досягнутий шляхом оцінки симптомів тривожних розладів по завершенню гострої фази психозу (Temmingh \& Stein, 2015). Логічно припустити, що тяжкість проявів психотичних симптомів у гострій фазі захворювання визначатиме ступінь тяжкості супутніх тривожних розладів.

Симптоми соціальної тривожності широко поширені серед амбулаторних хворих на шизофренію і тісно пов'язані з соціальним функціонуванням (Aikawa et al., 2018).

Коли стан пацієнтів із шизофренією ускладнено депресією, коморбідність тривожних розладів значно ускладнює ступінь її тяжкості (Hung et al., 2019).

Симптоми тривожних розладів можуть маскувати деякі соматичні хворобливі стани (дисфункцію надниркових залоз, аритмію, бронхіальну астму, цукровий діабет, синдром подразненої товстої кишки, інфаркт міокарда, судомні напади, захворювання щитоподібної залози тощо) (Корнацький, Третяк \& Чаплинська, 2011; Чабан, 2014; Клебан, 2015; Сапон, 2016). Отже, необхідно диференціювати тривожні розлади 3 цими й іншими захворюваннями. Гіподіагностика таких станів зумовлена тим, що тривожні симптоми сприймаються пацієнтом, а нерідко й лікарем, як соматичні (Хаустова, 2019). (c) Zaviazkina Natalia, Riakhovska Tetiana

DOI (article): https://doi.org/10.32626/2227-6246.2019-46.135-156 http://journals.uran.ua/index.php/2227-6246 
Ідентифікація симптомів тривоги та лікування тривожних станів необхідні для досягнення оптимальних результатів у клініці ендогенних психічних захворювань. Однак їм не приділяють достатньо уваги в силу того, що їх складно виокремити на тлі основного захворювання i, як наслідок, застосувати ефективне лікування не вбачається можливим (Bosanac \& Castle, 2015). Можна загалом припустити, що ці труднощі погіршують стан хворих, підвищують потребу в догляді й підсилюють інвалідизацію, що призводить до низьких показників якості життя і профнепридатності.

Психологічна проблема тривоги має різноманітні аспекти дослідження. Поряд із вивченням відмінності між раціональною та патологічною тривогою часто поставало питання про взаємини цього феномену при м'яких амбулаторних формах тривожних розладів і психозах. У літературі неодноразово висвітлювалася широко відома феноменологічна відмінність беззмістовного вітального переживання тривоги i страху (Anxiety) й предметного афекту страху (Fear) (Steimer, 2002).

Порівняльний аналіз неврозів і психозів шляхом порівняння тривоги й страху проводився багатьма дослідниками. Однак, основна увага дослідників була орієнтована на виявлення відмінних характеристик тривоги при неврозах i психозах, а не на пошуки подібних механізмів. Слід зазначити, що в ході порівняльних досліджень цього феномену були знайдені й загальні моменти, але, як правило, це поширювалося на кількісні особливості тривоги, терапевтичну відповідь, а не на особливості адаптації до цього феномену, в тому числі - поведінку.

Багатоплановість і семантична невизначеність поняття тривоги у психологічних дослідженнях є наслідком використання його в різних значеннях. Розглядаючи роль тривоги в клініці ендогенних психічних захворювань, ми вважаємо за необхідне зупинитися на дослідженні розуміння раціональної та патологічної тривоги, що й стало метою нашої статті.

(C) Zaviazkina Natalia, Riakhovska Tetiana DOI (article): https://doi.org/10.32626/2227-6246.2019-46.135-156 


\section{Завдання статті}

1. Здійснити аналіз тривоги як наукової категорії.

2. Розкрити психологічні особливості раціональної та патологічної тривоги.

3. Дослідити психологічні особливості раціональної та патологічної тривоги в клініці ендогенних психічних захворювань.

4. Обгрунтувати доцільність вивчення ролі тривоги в клініці ендогенних психічних захворювань.

\section{Методи та методики дослідження}

У дослідженні використано теоретичний аналіз наукової літератури, що дало змогу з'ясувати підходи сучасних науковців до розуміння тривоги та тривожних станів. За допомогою порівняння, як методу дослідження, було описано дефініції тривоги і тривожних станів у психології та психіатрії, що дозволило сформулювати висновки щодо проведеного дослідження й визначити перспективи подальших наукових розвідок.

\section{Результати та дискусії}

Тривога є одним із найменш досліджених станів при шизофренії, не зважаючи на докази їі значного впливу на результат захворювання (Buonocore et al., 2017). Однак, не зважаючи на ці докази, причинно-наслідковий зв'язок між підвищеним рівнем тривоги та клінічним результатом залишається невизначеним. Іншими словами, до цього часу не визначено напевно, тривога впливає на клінічні наслідки, чи останні впливають на те, як сприймається занепокоєння.

Багато змінних сприяють виникненню труднощів в управлінні тривожністю, включаючи «чинники навколишнього середовища», такі як життєві події, а також інші аспекти, такі як психопатологія і когнітивні порушення (Мауо et al., 2017).

(C) Zaviazkina Natalia, Riakhovska Tetiana

DOI (article): https://doi.org/10.32626/2227-6246.2019-46.135-156 
Розглядаючи питання проявів тривоги в клініці психічних ендогенних розладів, слід ураховувати те, що підвищена тривожність може бути викликана позитивними та негативними симптомами, які можуть вплинути на сприйняття здатності протидіяти новим стресорам (Norman et al., 1998; Siris, 2000). Проте існують дослідження, які не підтвердили цей взаємозв'язок, вони говорять про те, що тривога може бути незалежною від психопатології (Huppert et al., 2001).

Крім позитивних і негативних симптомів, когнітивні порушення також, здається, мають вирішальне значення для управління тривожністю. Наприклад, було доведено, що когнітивні порушення можуть заважати оцінці й реакції на стресові чинники, що призводить до того, що пацієнти вибирають неадекватні стратегії виживання, такі як уникнення від проблеми чи ізоляція (Lysaker et al. 2005).

Загалом, здатність справлятися з тривогою вимагає великих когнітивних ресурсів, тому хворі на шизофренію можуть зазнавати труднощів у подоланні тривоги, в тому числі внаслідок дефіциту когнітивних функцій.

Шизофренія - руйнівний розлад, що сильно впливає на функціонування та якість життя пацієнтів, часто може бути хронічним i виснажливим психічним захворюванням, що призводить до порушень у клінічному, психосоціальному й економічному функціонуванні.

Але, перш ніж розглядати аспекти проявів і наслідків тривожних станів у хворих на шизофренію, необхідно чітко визначити конструкт тривоги. Так, важливо відзначити, що тривога - це нормальна емоція й на своєму основному рівні $\epsilon$ частиною еволюції. 3 еволюційної точки зору вона адаптивна, оскільки сприяє виживанню, спонукаючи людину триматися якомога далі від небезпеки. Тривога є універсальним феноменом, пов'язаним із реакцією на стрес. Ї̈̈ призначення полягає в адаптації, мобілізації всіх сил організму для швидкої зміни поведінки й пристосування до змінених умов існування.

(C) Zaviazkina Natalia, Riakhovska Tetiana DOI (article): https://doi.org/10.32626/2227-6246.2019-46.135-156 
DOI: https://doi.org/10.32626/2227-6246.2019-46

Тривога може бути визначена як набір поведінкових, когнітивних і фізіологічних реакцій, що виникають без чітко визначеної зовнішньої загрози. Крім того, слід зазначити, що тривога необов'язково пов'язана з чітко визначеною фізіологічною відповіддю. 3 іншого боку, тривога являє собою взаємодію між стимулами зовнішнього середовища, стресорами та специфічними механізмами реагування на них (Pfaff \& Joels, 2017). Тривога може розглядатися як компонент реагування на стрес, так і як потенційний стресор.

Поняття тривоги стало використовуватися в лексиконі людства задовго до появи наукової психіатрії. Греко-римські філософи й лікарі чітко ідентифікували тривогу як стан, що має явний негативний вплив, і як окремий розлад. Крім того, стародавня філософія пропонувала методи лікування тривоги, які не надто далекі від сучасних когнітивних підходів (Crocq, 2015).

Наукове та клінічне вивчення тривоги почалося значно пізніше. Як психопатологічний феномен тривогу стали розглядати в кінці XIX ст. Починаючи з XX ст., у психіатричних класифікаціях тривога класифікується як розлад, рівень клінічної оцінки якого залежить від порога між нормальною адаптивною тривогою в повсякденному житті та патологічною тривогою, що вимагає лікування.

Цілеспрямоване психіатричне вивчення тривоги почалося в 1895 р., коли засновник психоаналізу S. Freud у peзультаті своїх клінічних досліджень виокремив так званий «невроз тривоги» - «Die Angstneurose» (Freud, 1926). Згідно з його теорією, певні переживання, що мали місце в житті людини (дії, імпульси, думки чи спогади), надто болючі або породжують сильну тривогу і витісняються зі свідомості, а ті сили, які призвели до витіснення події з пам'яті, мобілізуються, перешкоджаючи їх відновленню у свідомості (Freud, 1926). Тут діє фізіологічний механізм, близький до механізму «охоронного» гальмування, коли гальмування при надпотужних порушеннях захищає кору від зайвого перезбудження, і саме тому різкі афективні переживання, болісні й неC Zaviazkina Natalia, Riakhovska Tetiana

DOI (article): https://doi.org/10.32626/2227-6246.2019-46.135-156 http://journals.uran.ua/index.php/2227-6246 
прийнятні для суб'єкта, активно гальмуються, «витісняються» зі свідомості, забуваються суб’єктом (Freud, 1926). Коли витіснені ідеї загрожують вирватися на свідомий рівень, вони можуть знову викликати тривогу, і тому придушуються заново. У результаті людина переживає нескінченний підсвідомий конфлікт. В основі витіснення вирішальне значення має сильна тривога (Freud, 1926). Тривога - емоційний стан, схожий на той, що ми переживаємо, коли піддаємося загрозі ззовні. Вона є функцією «Его», її призначення - у попередженні людини про загрозу, що насувається, яку треба зустріти або уникнути. Тривога дає змогу особистості реагувати в загрозливих ситуаціях адаптивним способом. Витіснення можна розглядати як первинний, вихідний захисний механізм, який позбавляє людину від болісного для неї переживання тривоги, але досить часто витіснені думки й спонукання не вдається утримати на підсвідомому рівні, та разом з ними назовні проривається і тривога, пов'язана з ними. Унаслідок цього починають діяти різні додаткові захисні механізми, функція яких - зміцнення «греблі», що стримує заборонені імпульси. Серед них - заміщення, раціоналізація, реактивне утворення, проекція, регресія, сублімація й ізоляція (інтелектуалізація). Витіснення залежить від наявності загрози «Его» (основна загроза самооцінці), а не від простої неприємності або загрози. Коли причина витіснення (загроза «Его») зникає, то витіснений зміст повертається до свідомості. Якщо загроза усунута, то для витісненого матеріалу стає безпечним повернення на рівень усвідомлення (Freud, 1926).

K. Horney не вважала, що тривога є необхідним компонентом у психіці людини. Згідно з її соціокультурною теорією особистості, етіологія невротичної поведінки закладена в порушених взаємостосунках дитини та батьків. Усе те, що у відносинах із батьками руйнує відчуття безпеки у дитини, призводить до базальної тривоги. Нормальний розвиток дитини можливий через відчуття любові, прийняття себе, почуття безпеки (Horney, 2007).

(C) Zaviazkina Natalia, Riakhovska Tetiana DOI (article): https://doi.org/10.32626/2227-6246.2019-46.135-156 
DOI: https://doi.org/10.32626/2227-6246.2019-46

У своїй книзі «Втеча від свободи» (Escape from Freedom), яка вийшла у 1942 р., E. Fromm розкриває поняття тривоги через ідею формування деструктивного соціального характеру, внаслідок певних міжособистісних відносин. Не що інше, як тривога, змушує індивіда бігти від свободи. Ця тривога викликана міжособистісними відносинами, які одночасно $є$ i макросоціальними. Індивіда турбують не персоніфіковані об'єктні фігури його близьких, а безособові фігури-символи, що втілюють макросоціальні відносини тієї соціальної системи, у якій індивід існує (Fromm, 1994). Отже, виходячи 3 міркувань, що описує Е. Fromm, імовірно, що людина може відчувати тривогу по-різному, залежно від типу соціального характеру, до формування якого вона схильний. E. Fromm вважає, що всі люди відчувають тривогу в зв'язку із самотністю, з якою кожна людська істота стикається, неминуче відриваючись від природних коренів (Fromm, 1994).

Концепція тривоги в ідеї міжособистісних відносин находить своє відображення і в роботах H. Sullivan. Так, у 1948 р. у журналі «Психіатрія» (Рsychiatry) опубліковано його статтю «Значення тривоги для психіатрії та для життя» (The Meaning of Anxiety in Psychiatry and in Life), присвячену концепту тривоги. Детальніше цю тему розкрито в роботі «Міжособистісна теорія психіатрії» (The interpersonal theory of psychiatry). H. Sullivan вважає, що походження тривоги викликано не соціальним середовищем узагалі, як потужною брилою, що пригнічує індивіда, як це описує E. Fromm, а конкретними патернами міжособистісних відносин. Так, за його теорією, тривога у процесі розвитку особистості викликається несхваленням із боку інших. Так чи інакше, це несхвалення свідчить про загрозу інтересам і потребам особистості, й тому вона сприймає його у формі тривоги. На етапі дитинства тривога виходить від несхвалення матір'ю і передається дитині емпатійно. На етапі юнацтва і наступних етапах розвитку тривога виходить від несхвалення оточення, яке загрожує самооцінці. Люди викликають в інших три(c) Zaviazkina Natalia, Riakhovska Tetiana

DOI (article): https://doi.org/10.32626/2227-6246.2019-46.135-156 
вогу, спрямовану на зниження самоповаги. Така агресивна дія може переадресовуватися, і людина зі зниженою самооцінкою прагне знизити іiі в оточення, викликавши в них тривогу (Sullivan, 1999).

Продуктом міжособистісних відносин тривогу вважав i ще один відомий психолог - британський психіатр і психоаналітик R. Laing. Згідно з його теорією, уникненням від тривоги є формування психозу (Laing, 1965). У своїй роботі «Undivided Self» R. Laing приділяє увагу детермінантам психотичних розладів, що містяться в характері міжособистісного спілкування хворих на шизофренію з їх близькими і соціальної психології їх сімейних та інших груп. Такі відносини, за R. Laing, викликають тривогу в будь-якої особи, але тільки людина з високим порогом онтологічної невпевненості вибирає аварійним виходом із тієї безвиграшної позиції те, що психіатри діагностують як «шизофренія». Онтологічно невпевнена особистість не здатна переносити спілкування, під час якого інші ставляться до неї, як до речі. На відміну від звичайної людини, вона набагато вразливіша щодо такого роду спілкування. Намагаючись захиститися від цих відносин, що перетворюють онтологічно невпевнену особистість у річ, вона починає відчужуватися від свого тіла й ототожнює себе з безрозсудним собою (unembodied self). Така особистість боїться того, що інший «поглине» їі, «увірветься в неї» або «перетворить їі на камінь» (Laing, 1965). Тобто, вона боїться того нелюдського ставлення, до якого звичайні люди не такі чутливі та яке в нашому суспільстві є найпоширенішим типом спілкування.

У міру вивчення феномену тривоги стали виникати труднощі у встановленні відмінності між раціональною тривогою i патологічною. Поділ тривоги на «раціональну» і «патологічну» існує історично. Так, A. Freud, I. Павлов, П. Анохін говорять про цей розподіл як про факт, що виникає власне з теорії афектів (Freud, 1993; Павлов, 1951; Анохін, 1935).

Отже, основну відмінність раціональної тривоги від патологічної можна розглядати в тому, що перша є вираженням

(C) Zaviazkina Natalia, Riakhovska Tetiana DOI (article): https://doi.org/10.32626/2227-6246.2019-46.135-156 
людської безпорадності перед обличчям реальної небезпеки, тоді як остання, загалом, є наслідком передбачуваної ворожості. Різниця, яку виокремлюе S. Freud, полягає в тому, що раціональна тривога є реакцією на зовнішню загрозу, а невротична - на ту, що спонукає вимогу (Freud, 1926).

Невротична тривога, на думку R. Мay, - це реакція на загрозу, яка, по-перше, неадекватна об'єктивній небезпеці, по-друге, має в собі витіснення (дисоціацію) та інші прояви механізмів захисту i, отже, по-третє, людина обмежує якісь свої дії за допомогою різних невротичних захисних механізмів. При раціональній тривозі людина може конструктивно поводитися з нею на свідомому рівні або ж тривога знижується, коли змінюється об'єктивна ситуація (Мау, 2011).

На думку Ю. Нуллер, в основі реакції раціональної й патологічної тривоги лежать одні й ті ж самі процеси, але в другому випадку вони виражені набагато інтенсивніше. Раціональна тривога викликається реальною ситуацією і $€$ за інтенсивністю й тривалістю адекватною їй, а патологічна - цілком обумовлена хворобливим процесом або надмірно важка і тривала, порівняно з причиною, яка їі викликала (Нуллер, 1988).

Корінна відмінність патологічної тривоги від раціональної полягає в тому, що вона істотно порушуе якість життя людини і їі діяльність. Такої точки зору дотримуються багато дослідників цієї царини.

Дослідження тривоги не обмежувалися вивченням відмінності між раціональною і патологічною тривогою. Фокус уваги також був спрямований на розгляд питання феномену тривоги за різних нозологічних форм.

C. Jung вважав, що причина виникнення тривоги єдина, незалежно від нозологічної приналежності. C. Jung описує тривогу як реакцію свідомості індивіда на вторгнення ірраціональних спонукань і образів колективного несвідомого. Якщо внутрішньо індивідуальні бар'єри на шляху ірраціональних прагнень і образів колективного несвідомого є тон(c) Zaviazkina Natalia, Riakhovska Tetiana

DOI (article): https://doi.org/10.32626/2227-6246.2019-46.135-156 
кими, існує небезпека психозу, який супроводжує тривога. Основні компоненти колективного несвідомого опосередковано керують поведінкою людини і при психозах, і при неврозах (Jung, 1967).

Деякі дослідники порівнювали невротичну і психотичну тривогу через когнітивний зміст, психодинамічні концепції, що обумовлюють клінічну картину захворювання. K. Goldstein проводить аналогію між вираженою тривогою невротичного рівня і тривогою при виникненні психозів. Коли виникає сильна емоція, то зрозуміло, що людина не здатна сказати та не знає, чого вона боїться. Особливо гостро це помітно у хворих при виникненні психозу, але іноді те ж саме явище можна спостерігати й не за таких крайніх обставин. Сильну тривогу людина сприймає як руйнування самої себе, «припинення існування власної особистості» (Goldstein, 1964).

S. Tsirkin проводить психопатологічну диференціацію тривоги. Спільну рису невротичної та психотичної тривоги він бачить у тому, що в обох випадках переживається небезпека або загроза. Відмінність між видами тривоги він пояснює джерелом небезпеки, яке у разі невротичної тривоги, зазвичай, являє собою щось нове або змінене, випадкове. За психотичної тривоги загроза дифузна, в ній прихована навмисність (S. Tsirkin, 1995).

Загальним для невротичної та психотичної тривоги є безпредметність переживань. Ю. Савенко вказує на складність розмежування невротичної та психотичної боязні. Короткочасні (від 15-20 хвилин до 1-2 годин) напади страху з конкретним змістом, на тлі наявних побоювань, характерні й для неврозів, і для психозів, але є лише стадією в розвитку останніх. Структурна різниця між психотичним (вітальним) страхом і невротичним полягає в беззмістовному, нелокалізованому, дифузному характері переживання. Дуже характерним для афективних психозів є почуття безпорадності, аж до розгубленості на висоті вітального страху (Савенко, 1974). 


\section{Висновки}

Систематизоване наукове вивчення тривоги як психопатологічного утворення обумовлено, з одного боку, високою поширеністю тривожних станів при різних нозологічних кваліфікаціях, а з іншого - багатогранністю психопатологічного простору проявів тривоги.

Більшість науковців відрізняють патологічну тривогу від раціональної за рівнем: інтенсивності афекту і його тривалістю, адекватності небезпеки, що існує, включення механізмів психологічного захисту, впливу на якість життя пацієнта.

Раціональна тривога має адаптаційний характер, мобілізує всі сили організму для пристосування до нових умов існування. Тим самим, завдяки своєму адаптаційному характеру, раціональна тривога є проміжним варіантом між істинною тривогою і страхом. Людина, оцінюючи загрозливу ситуацію, перебуває в стані «напівстраху, напівтривоги». При патології функціонує, швидше відбувається перехід істинної тривоги у страх (безглузда ідея при шизофренії, агорафобія або інші види фобії при тривожних розладах). Отже, в раціональній тривозі вже закладено елементи патологічної тривоги.

Клінічно значуща тривога може передувати виникненню ендогенного психічного захворювання і бути пов'язана з раннім дебютом захворювання та виступати як основним симптомом, так і бути супутньою до основного діагнозу.

До теперішнього часу проблемі порівняльного аналізу феномену тривоги при невротичних i психотичних станах присвячена велика кількість науково-практичних робіт. Однак основна увага більшості дослідників цього питання була спрямована на підтвердження відмінностей, а не на пошуки механізмів, які їх об’єднують. Подібними механізмами можуть стати адаптаційні стратегії, способи подолання тривоги.

Загальні закономірності формування адаптаційних механізмів до тривоги у психічно здорових людей і осіб, які страждають психічними розладами, можуть сприяти гумані(C) Zaviazkina Natalia, Riakhovska Tetiana

DOI (article): https://doi.org/10.32626/2227-6246.2019-46.135-156 http://journals.uran.ua/index.php/2227-6246 
зації ставлення суспільства до психічно хворих, що є одним із чинників дестигматизації в психіатрії.

\section{Література}

Анохин П. К. Проблема центра и периферии в физиологии нервной деятельности. Горький : Медицина, 1935. 52 с.

Клебан К. І. Хронобіологічні особливості непсихотичних психічних розладів у пацієнтів з метаболічним синдромом: автореф. дис. ... канд. мед. наук: спец. 14.01.16. Київ, 2015. 18 с.

Корнацький В. М., Третяк I. В., Чаплинська Н. В. Особливості емоційного стану пацієнтів з артеріальною гіпертензією. Украӥнський кардіологічний журнал. 2011. № 3. С. 55-59.

Мэй Р. Смысл тревоги / пер с англ. Москва : Институт общегуманитарных исследований, 2011. 416 с.

Нуллер Ю. Л., Михаленко И. Н. Аффективные психозы. Ленинград : Медицина, 1988. 264 с.

Павлов И. П. Полное собрание сочинений. Москва : Издательство Академии наук СССР, 1951. Т. 2, кн. 2. 588 с.

Савенко Ю. С. Тревожные психотические синдромы (клинико-экспериментальное исследование): автореф. дис. ... д-ра мед. наук: спец. 14.00.16. Москва, 1974. 48 с.

Салливан Г. С. Интерперсональная теория в психиатрии / пер с англ. Москва : Ювента, КСП+, 1999. 352 с.

Сапон Д. М. Тривожно-депресивні розлади при ХБС і фіброміалгії: автореф. дис. ... канд. мед. наук: спец. 14.00.16. Київ, 2016. 22 с.

Фрейд А. Психология Я и защитные механизмы / пер с англ. Москва : Педагогика, 1993. 144 с.

Хаустова О. О. Психосоматичні маски тривоги. Украӥнський медичний часonuc. 2019. № 4. T. 1-VI/VII. C. 132.

Хорни К. Наши внутренние конфликты. Конструктивная теория невроза. Москва : Академический Проект, 2007. 218 с.

Циркин С. Ю. Концептуальная диагностика функциональных расстройств при шизофрении: диатез и шизофрения. Социальная $u$ клиническая психиатрия. 1995. № 2. С. 114-118.

Чабан О. С. Депресивні розлади у пацієнтів похилого віку: проблеми діагностики і терапії. Hейро News. 2014. № 2/1. С. 14-20.

Aikawa, Sayaka; Kobayashi, Hiroyuki; Nemoto, Takahiro; Matsuo, Satoshi; Wada, Yo; Mamiy, Noriyuki; et al. (2018). Social anxiety and risk factors in patients with schizophrenia: Relationship with duration of untreated psychosis. Psychiatry Research, 263, 94-100. Retrieved from https://doi.org/10.1016/j.psychres.2018.02.038.

(C) Zaviazkina Natalia, Riakhovska Tetiana

DOI (article): https://doi.org/10.32626/2227-6246.2019-46.135-156 
Bermanzohn, P. C., Porto, L., Siris, S. G., Stronger, R., Hwang, M. Y., \& Pollack, S. (2001). Hierarchy, Reductionism, and "Co-morbidity» in the Diagnosis of Schizophrenia. In M. Y. Hwang, \& P. C. Bermanzohn (Eds.). Schizophrenia and Co-morbid Conditions: Diagnostic and Treatment (pp. 1-29). Washington, DC : American Psychiatric Press. Bosanac, Peter; \& Castle, David (2015). How should we manage anxiety in patients with schizophrenia? Australasian psychiatry: bulletin of Royal Australian and New Zealand College of Psychiatrists, 23, 4, 374-377. Retrieved from https://doi.org/10.1177/1039856215588207.

Braga, Raphael J.; Reynolds, Graham P.; Siris, Samuel G. (2013). Anxiety comorbidity in schizophrenia. Psychiatry Research, 210 (1), 1-7. Retrieved from https://doi.org/10.1016/j.psychres.2013.07.030.

Buonocore, M., Bosia, M., Bechi, M., Spangaro, M., Cavedoni, S., Cocchi, F., et al. (2017). Targeting anxiety to improve quality of life in patients with schizophrenia. European Psychiatry, 45, 129-135. Retrieved from https://doi.org/10.1016/j.eurpsy.2017.06.014.

Crocq, Marc-Antoine (2015). A history of anxiety: from Hippocrates to DSM. Dialogues Clin Neurosci, 17 (3), 319-325.

Freud, S. (1926). Inhibitions, symptoms and anxiety. In J. Strachey, \& A. Freud (Eds.). The standard edition of the complete psychological works of Sigmund Freud. London : The Hogarth Press.

Fromm, Erich (1994). Escape from Freedom. Henry Holt and Company.

Goldstein, K. (1964). Methodological approach to the study of schizophrenic thought disorder. In Language and Thought in Schizophrenia, J. S. Kasanin (Ed.). New York : Norton, (pp. 17-39).

Hung, Ching-I; Liu, Chia-Yih; Yang, Ching-Hui; Gan, Shu-Ting (2019). Comorbidity with more anxiety disorders associated with a poorer prognosis persisting at the 10-year follow-up among patients with major depressive disorder. Journal of Affective Disorders, 260, 97-104. Retrieved from https://doi.org/10.1016/j.jad.2019.08.085.

Huppert, J. D., Weiss, K. A., Lim, R., Pratt, S., \& Smith, T. E. (2001). Quality of life in schizophrenia: Contributions of anxiety and depression. Schizophrenia Research, 51, 171-180. Retrieved from https:// doi.org/10.1016/S0920-9964(99)00151-6.

Jung, C. G. (1967). Symbols of Transformation. Collected Works of C. G. Jung (Vol. 5). Princeton, New Jersey : Princeton University Press.

Karpov, B., Joffe, G., Aaltonen, K., Suvisaari, J., Baryshnikov, I., Näätänen, P., et al. (2016). Anxiety symptoms in a major mood and schizophrenia spectrum disorders. European Psychiatry, 37, 1-7. Retrieved from https://doi.org/10.1016/j.eurpsy.2016.04.007.

Laing, R. D. (1965). The Divided Self: An Existential Study in Sanity and Madness. Penguin Psychology.

(C) Zaviazkina Natalia, Riakhovska Tetiana

DOI (article): https://doi.org/10.32626/2227-6246.2019-46.135-156 
Lysaker, P. H., Davis, L. W., Lightfoot, J., Hunter, N., \& Stasburger, A. (2005). Association of neurocognition, anxiety, positive and negative symptoms with coping preference in schizophrenia spectrum disorders. Schizophrenia Research, 80, 163-171. Retrieved from https:// doi.org/10.1016/j.schres.2005.07.005.

Mayo, D., Corey, S., Kelly, L. H., Yohannes, S., Youngquist, A. L., Stuart, B. K., et al. (2017). The role of trauma and stressful life events among individuals at clinical high risk for psychosis: A review. Frontiers in Psychiatry. (Vol. 8). Retrieved from https://doi.org/10.3389/ fpsyt.2017.00055.

Norman, R. M. G., Malla, A. K., Cortese, L., \& Diaz, F. (1998). Aspects of dysphoria and symptoms of schizophrenia. Psychological Medicine, 28 (6), 1433-1441. Retrieved from https://doi.org/10.1017/ S003329179800751X.

Pfaff, D., \& Joels, M. (2017). Hormones, Brain, and Behavior. (Vol. 5, pp. 133-158). Oxford : Academic Press.

Siris, Samuel G. (2000). Depression in schizophrenia: Perspective in the Era of «Atypical» Antipsychotic Agents. American Journal of Psychiatry, 157 (9), 1379-1389. Retrieved from https://doi.org/10.1176/ appi.ajp.157.9.1379.

Steimer, T. (2002). The Biology of Fear and Anxiety Related Behaviors. Dialogues in clinical neuroscience, 4, 231-249.

Temmingh, H., \& Stein, DJ. (2015). Anxiety in patients with schizophrenia: Epidemiology and management. CNS Drugs, 29 (10), 819-832. Retrieved from https://doi.org/10.1007/s40263-015-0282-7.

\section{References}

Anokhin, P. K. (1935). Problema tsentra i periferii $v$ fiziologii nervnoi deiatelnosty [The problem of the center and periphery in the physiology of nervous activity]. Gorkiy: Meditsina [in Russian].

Kleban, K. I. (2015). Khronobiolohichni osoblyvosti nepsykhotychnykh psykhichnykh rozladiv u patsiientiv z metabolichnym syndromom. [Chronobiological peculiarities of non-psychotic mental disorders in patients with metabolic syndrome]. Extended abstract of Candidate's thesis. Kyiv: Naukovyi svit [in Ukrainian].

Kornatskyi, V. M., Tretiak, I. V., \& Chaplinska, V. V. (2011). Osoblyvosti emotsiinoho stanu patsiientiv z arterialnoiu hipertenziieiu [Features of emotional state of patients with arterial hypertension]. Ukrainskyi kardiolohichnyi zhurnal - Ukrainian cardiological jounal, 3, 55-59 [in Ukrainian].

May, R. (2011). Smysl trevogi [The Meaning of Anxiety]. Moskva: Institut obschegumanitarnykh issledovaniy [in Russian].

(C) Zaviazkina Natalia, Riakhovska Tetiana

DOI (article): https://doi.org/10.32626/2227-6246.2019-46.135-156 
Nuller, Yu. L., \& Mikhalenko, I. N. (1988). Affektivnye psikhozy [Affective psychoses]. Leningrad: Meditsina [in Russian].

Pavlov, I. P. (1951). Polnoe sobranie sochineniy [Full composition of writings]. (Vol. 2, Part 2). Izdatelstvo Akademia nauk SSSR [in Russian].

Savenko, Y. S. (1974). Trevozhnye psikhoticheskie sindromy [Anxious Psychotic Syndromes]. Extended abstract of Doctor's thesis. Moskva [in Russian].

Sullivan, H. S. (1999). Interpersonalnaia teoriia v psikhiatrii [Interpersonal Theory and Psychotherapy]. (Trans). Moskva: Yuventa, KSP+ [in Russian].

Sapon, D. M. (2016). Tryvozhno-depresyvni rozlady pry khronichnomu boliovomu syndromi i fibromialhii [Anxiety-depressive disorders in chronic pain and fibromyalgia]. Extended abstract of Candidate's thesis. Kyiv, MOZU UNDI sotsialnoi i sudovoi psykhiatrii ta narkolohii [in Ukrainian].

Freud, A. (1993). Psikhologiia Ya i zashchitnye mekhanizmy [Psychology of Self and defense mechanisms]. (Trans.). Moskva. Pedagogika [in Russian].

Khaustova, O. O. (2019). Psykhosomatychni masky tryvohy [Psychosomatic masks of anxiety]. Ukrainskyi medychnyi chasopys - Ukrainian medical journal, 4, 1 (VI/VII), 132 [in Ukrainian].

Horney, K. (2007). Nashi vnutrennie konflikty. Konstruktivnaia teoriia nevroza. [Our Inner Conflicts. Constructive theory of neurosis]. Moskva: Akademicheskii Proekt [in Russian].

Tsirkin, S. Y. (1995). Konceptualnaia diagnostika funktsionalnykh rasstroistv pri shizofrenii: diatez i shizofreniia [Conceptual diagnosis of functional disorders in schizophrenia: diathesis and schizophrenia]. Socialnaia i klinicheskaia psikhiatriia. Social and clinical psychiatry, 2, 114-118 [in Russian].

Chaban, O. S. (2014). Depresyvni rozlady u patsiientiv pokhyloho viku: problemy diahnostyky i terapii [Depressive disorders in elderly patients: problems of diagnosis and therapy]. Neuro News, 2/1, 14-20 [in Ukrainian].

Aikawa Sayaka, Kobayashi Hiroyuki, Nemoto Takahiro, Matsuo Satoshi, Wada Yo, Mamiy Noriyuki, et al. (2018). Social anxiety and risk factors in patients with schizophrenia: Relationship with duration of untreated psychosis. Psychiatry Research, 263, 94-100. Retrieved from https://doi.org/10.1016/j.psychres.2018.02.038.

Bermanzohn, P. C., Porto, L., Siris, S. G., Stronger, R., Hwang, M. Y., \& Pollack, S. (2001). Hierarchy, Reductionism, and «Co-morbidity» (c) Zaviazkina Natalia, Riakhovska Tetiana

DOI (article): https://doi.org/10.32626/2227-6246.2019-46.135-156 http://journals.uran.ua/index.php/2227-6246 
in the Diagnosis of Schizophrenia. Hwang, M.Y., Bermanzohn, P.C. (Eds.), Schizophrenia and Co-morbid Conditions: Diagnostic and Treatment. American Psychiatric Press, Washington, DC.

Bosanac, Peter \& Castle, David. (2015). How should we manage anxiety in patients with schizophrenia? Australasian psychiatry: bulletin of Royal Australian and New Zealand College of Psychiatrists, 23, 4, 374377. Retrieved from https://doi.org/ 10.1177/1039856215588207.

Braga Raphael J., Reynolds Graham P., Siris Samuel G. (2013). Anxiety comorbidity in schizophrenia. Psychiatry Research, 210 (1), 1-7. Retrieved from https://doi.org/10.1016/j.psychres.2013.07.030

Buonocore, M., Bosia, M., Bechi, M., Spangaro, M., Cavedoni, S., Cocchi, F. et al., (2017). Targeting anxiety to improve quality of life in patients with schizophrenia. European Psychiatry, 45, 129-135. Retrieved from https://doi.org/10.1016/j.eurpsy.2017.06.014

Crocq, Marc-Antoine (2015). A history of anxiety: from Hippocrates to DSM. Dialogues Clin Neurosci, 17 (3), 319-325.

Freud, S. (1926). Inhibitions, symptoms and anxiety. In J. Strachey, \& A. Freud (Eds.). The standard edition of the complete psychological works of Sigmund Freud, (pp. 77-175). London: The Hogarth Press. Fromm Erich (1994). Escape from Freedom. Henry Holt and Company.

Goldstein, K. (1964). Methodological approach to the study of schizophrenic thought disorder. In: Language and Thought in Schizophrenia, J.S. Kasanin. (Ed.) (pp. 17-39). New York: Norton.

Hung Ching-I, Liu Chia-Yih, Yang Ching-Hui, Gan ShuTing (2019). Comorbidity with more anxiety disorders associated with a poorer prognosis persisting at the 10 -year follow-up among patients with major depressive disorder. Journal of Affective Disorders, 260, 97-104. Retrieved from https://doi.org/10.1016/j.jad.2019.08.085.

Huppert, J. D., Weiss, K. A., Lim, R., Pratt, S., \& Smith, T. E. (2001). Quality of life in schizophrenia: Contributions of anxiety and depression. Schizophrenia Research, 51, 171-180. Retrieved from https:// doi.org/10.1016/S0920-9964(99)00151-6.

Jung, C. G. (1967). Symbols of Transformation, Collected Works of C.G. Jung (Vol. 5), Princeton, New Jersey: Princeton University Press.

Karpov, B., Joffe, G., Aaltonen, K., Suvisaari, J., Baryshnikov, I., Nддtдnen, P., et al. (2016). Anxiety symptoms in a major mood and schizophrenia spectrum disorders. European Psychiatry, 37, 1-7. Retrieved from https://doi.org/10.1016/j.eurpsy.2016.04.007

Laing, R. D. (1965). The Divided Self: An Existential Study in Sanity and Madness. Penguin Psychology.

(C) Zaviazkina Natalia, Riakhovska Tetiana

DOI (article): https://doi.org/10.32626/2227-6246.2019-46.135-156 
Lysaker, P. H., Davis, L. W., Lightfoot, J., Hunter, N., Stasburger, A., (2005). Association of neurocognition, anxiety, positive and negative symptoms with coping preference in schizophrenia spectrum disorders. Schizophrenia Research, 80, 163-171. Retrieved from https://doi.org/10.1016/j.schres.2005.07.005.

Mayo, D., Corey, S., Kelly, L. H., Yohannes, S., Youngquist, A. L., Stuart, B.K. et al., (2017). The role of trauma and stressful life events among individuals at clinical high risk for psychosis: A review. Frontiers in Psychiatry. (Vol. 8). Retrieved from https://doi. org/10.3389/fpsyt.2017.00055.

Norman, R. M. G, Malla, A. K., Cortese, L., \& Diaz, F., (1998). Aspects of dysphoria and symptoms of schizophrenia. Psychological Medicine, 28 (6), 1433-1441. Retrieved from https://doi.org/10.1017/ S003329179800751X.

Pfaff, D., \& Joels, M., (2017). Hormones, Brain, and Behavior, 5, 133158. Oxford: Academic Press.

Siris Samuel G., M. D. (2000). Depression in schizophrenia: Perspective in the Era of "Atypical» Antipsychotic Agents. American Journal of Psychiatry, 157, (9), 1379-1389. Retrieved from https://doi.org/ 10.1176/appi.ajp.157.9.1379.

Steimer, T. (2002). The Biology of Fear and Anxiety Related Behaviors. Dialogues in clinical neuroscience, 4, 231-249.

Temmingh, H., Stein, DJ. (2015). Anxiety in patients with schizophrenia: Epidemiology and management. CNS Drugs, 29 (10), 819-832. Retrieved from https://doi.org/10.1007/s40263-015-0282-7.

Завязкіна Наталія, Ряховська Тетяна. Проблематика досліджень психологічних особливостей раціональної та патологічної тривоги в клініці ендогенних психічних захворювань

\section{АНОТАЦІЯ}

У статті розглянуто теоретичні аспекти історії розвитку уявлень про тривогу і тривожні стани. Особливої уваги в роботі надано аналізу розуміння рачіональної та патологічної тривоги й характерних особливостей ї̈ проявів при невротичних і психотичних станах. Методи дослідження представлені порівнянням і співвіднесенням існуючих історичних і сучасних теорій і підходів до вивчення тривоги й тривожних станів, їх дефрініції в психології та психіатрії, що й стало теоретико-методологічною основою дослідження.

(C) Zaviazkina Natalia, Riakhovska Tetiana

DOI (article): https://doi.org/10.32626/2227-6246.2019-46.135-156 http://journals.uran.ua/index.php/2227-6246 
DOI: https://doi.org/10.32626/2227-6246.2019-46 2019. Випуск 46

З'ясовано, що більшість авторів відрізняють патологічну тривогу від раціональної за рівнем: інтенсивності афекту і його тривалістю, адекватності небезпеки, що існує, включення механізмів психологічного захисту, впливу на якість життя пацієнта.

Підкреслено, що раціональна тривога має адаптаційний характер, мобілізує всі сили організму для пристосування до нових умов існування. Тим самим завдяки своєму адаптаційному характеру раціональна тривога є проміжним варіантом між істинною тривогою і страхом. При патології швидше відбувається перехід істинної тривоги у страх (безглузда ідея при шизофренії, агорафобія або інші види фобії при тривожних розладах). Отже, в раціональній тривозі вже закладені елементи патологічної тривоги.

Зроблено висновок, що до теперішнього часу проблемі порівняльного аналізу феномену тривоги при невротичних і психотичних станах присвячено велику кількість науково-практичних робіт. Однак основну увагу більшості дослідників цього питання було направлено на підтвердження відмінностей, а не на пошуки механізмів, які їх об'єднують. Подібними механізмами можуть стати адаптаційні стратегії, способи подолання тривоги.

Ключові слова: тривога, страх, невротичний стан, рачіональна тривога, патологічна тривога, ендогенне психічне захворювання, адаптація.

Завязкина Наталия, Ряховская Татьяна. Проблематика исследования психологических особенностей рациональной и патологической тревоги в клинике эндогенных психических заболеваний

\section{АННОТАЦИЯ}

В статье рассмотрены теоретические аспекты истории развития представлений о тревоге и тревожных состояниях. Особое внимание в работе уделено анализу понимания рачиональной и патологической тревоги и характерных особенностей ее проявлений при невротических и психотических состояниях. Методы исследования представлены сравнением и соотнесением существующих исторических и современных теорий и подходов к изучению тревоги и тревожных состояний, их дефиниции в психологии и психиатрии, что послужило теоретико-методологической основой исследования.

(C) Zaviazkina Natalia, Riakhovska Tetiana DOI (article): https://doi.org/10.32626/2227-6246.2019-46.135-156 
DOI: https://doi.org/10.32626/2227-6246.2019-46

Выявлено, что большинство авторов отличают патологчческую тревогу от рациональной по уровню: интенсивности аффекта и его продолжительности, адекватности существующей опасности, включения механизмов психологической защиты, влияния на качество жизни пациента.

Подчеркнуто, что рациональная тревога имеет адаптационный характер, мобилизует все силы организма для приспособления к новым условиям существования. Тем самым благодаря своему адаптационному характеру рациональная тревога является промежуточным вариантом между истинной тревогой и страхом. При патологии быстрее происходит переход истинной тревоги в страх (бредовая идея при шизофрении, агорафобия или другие виды фобий при тревожных расстройствах). Таким образом, в рациональной тревоге уже заложены элементы патологической тревоги.

Сделан вывод, что к настоящему времени проблеме сравнительного анализа феномена тревоги при невротических и психотических состояниях посвящено большое количество научно-практических работ. Однако основное внимание большинства исследователей по данному вопросу было направлено на подтверждение различий, а не на поиски механизмов, которые их объединяют. Подобными механизмами могут стать адаптационные стратегии, способы преодоления тревоги.

Ключевые слова: тревога, страх, невротическое состояние, рациональная тревога, патологчческая тревога, эндогенное психическое заболевание, адаптация.

Original manuscript received September 21, 2019 Revised manuscript accepted October 17, 2019

(C) Zaviazkina Natalia, Riakhovska Tetiana

DOI (article): https://doi.org/10.32626/2227-6246.2019-46.135-156 http://journals.uran.ua/index.php/2227-6246 